\title{
AYDIN'DA ARAZİ TOPLULAŞTIRMASININ ARAZİ VARLIĞI ÜZERİNE ETKİSİ
}

\author{
Mahir PEKER, Necdet DAĞDELEN ${ }^{l}$
}

\begin{abstract}
Özet
Bu çalıșma, Aydın'da bulunan dokuz yerleșim biriminde uygulanan arazi toplulaștırma sahalarında toplam 4389 ha alanda yürütülmüştür. Çalışmada toplulaştırma öncesi ve sonrası araştırma alanında parsel büyüklükleri, işletme başına düşen parsel sayısına, parsellerin hisselilik durumları ve ortalama parsel büyüklüğü değerleri incelenmiştir. Çalışma sonucunda arazi toplulaştırması ile parsel sayısı 8465'den 4731'e düşmüştür. Toplulaştırma öncesinde ve sonrasında tek kişiye ait parsel oranları en yüksek değer almış olup toplulaştırmadan önce tek hisseli parsel sayısı 7088 iken, toplulaştırma sonunda tek hisseli parsel sayıs1 4080'e düşmüştür. Çalışmada proje sahasında ortalama parsel büyüklüğü 5,18 dekar'dan 9,28 dekara yükselmiştir. Toplulaştırma sonrası parsel büyüklükleri incelendiğinde toplam parsel sayıs1 4 731, parsellerin toplam alanı ise 41730 dekardır. 0-4,99 dekar arasında alana sahip parsel sayıs1 1955 , toplam parsel sayısına oranı ise $\% 41$; alan olarak ise 5905 dekardır. Diğer taraftan parsellerin \% 32'si 5-9,99 dekar büyüklüğünde olup toplam kapadıkları alan ise 11126 dekardır. 10 dekar üzerindeki parsel sayıları oranı ise yaklaşık \%25 dolayındadır. Sonuçta parsellerin büyük bir kısmı gerek alan gerekse sayı olarak 0-9,99 dekar grubunda toplanmıştır.
\end{abstract}

Anahtar sözcükler: Arazi toplulaştırması, ortalama parsel büyüklügüu, parsel sayısı

\section{Effects of Land Consolidation on Land Assets in Aydin Province}

\begin{abstract}
This study was carried out in the land consolidation areas of Aydın vicinity which has nine units. The study contains of 5454 enterprises which are in 43890 decares land. The size of the parcel, the number of parcels per farm, the status of shareholder parcel, the number of parcel and the average of parcel size were evaluated before and after of land consolidation in the study. The number of parcel decreased from 8465 to 4731 with the land consolidation in the province. Before and after of land consolidation a single shareholder parcel rate was determined as highest. Single shareholder parcel number was decreased from 7088 to 4080 before and after of land consolidation. The average parcel size increased from 5,18 to 9,28 decares. All the parcels reached agricultural road and became irrigated after land consolidation. Parcel sizes were evaluated after land consolidation and total size of the parcels were determined as $41730 \mathrm{da}$ and total parcel number as 4731 . The number of parcels sized between $0-4.99$ da is 1955 and its rate to total parcel number is $41 \%$, and the coverage of total area is 5905 da. $32 \%$ of the parcels sized between 5-9.99 da and covers totally 11126 da. Parcels larger than 10 da covers $25 \%$ of the total area. As a result, greatest proportion of parcels were in between the 0-9.99 da parcel size class.
\end{abstract}

Keywords: Land consolidation, the average of parsel size, the number of parcels.

\section{GíRIȘ}

Arazi toplulaştırması (AT) uygulamaları dar ve geniş anlamda olmak üzere iki şekilde yapılmaktadır (Takka, 1993). Dar anlamda AT; aynı şahıs veya çiftçi ailesine ait olan dağınık ve küçük yapıdaki arazi parçalarının ve hisselerinin bir araya getirilmesidir. $\mathrm{Bu}$ tanım çerçevesinde yapılan toplulaştırma faaliyetleri daha az masrafla ve kısa sürede tamamlandığı için, üretim artışı bakımından gerekli etkiyi sağlayamamaktadır. Geniş anlamda AT; tarımsal üretim tekniklerinin ekonomik olarak uygulanmasını, tarımsal sulama, zirai mücadele ve toprak koruma önlemlerinin alınmasını güçleştirecek şekilde parçalanmış, dağılmış ve şekilleri bozulmuş olan tarım arazilerini bir araya getirmek(toplamak), birleştirmek ve malik çiftçi ailelerinin yaşam şartlarını iyileştirmek için teknik ve sosyo-ekonomik yönden gerekli önlemleri almaktır.
Arazi toplulaştırma faaliyetleri, kaliteli ürün artışını sağlama hedefleri doğrultusunda yapılan ve tarım arazilerini tüm alt yapı hizmetleri (yol-sulama ağı, drenaj, toprak tesviyesi, yerleşim birimlerinin imarı vb.) ile birlikte bu hedeflere uygun hale getirmeye yönelik uygulamalı işlemlerin kompozisyonu niteliğindedir (Çay ve İnceyol 2000).

Bir başka deyişle arazi toplulaştırması, bitkisel ve hayvansal bazda verimin artırılmasına yönelik olarak; şahıs veya işletmelere ait olan parçalı ve küçük yapıdaki tarıma elverişsiz biçimde şekillenmiş olan arazilerin, modern tarım esaslarına göre birleştirilmesi, şekillendirilmesi ve düzenlenmesidir (Takka, 1993).

Tarımsal üretimde maksimum gelirin alınmasında işletmelerin büyüklüğü ve sayısı da önemlidir. Bu açıdan durumun incelenmesi amacıyla "Türkiye'de tarım işletmelerinin ortalama büyüklüğü ve sayısı" Çizelge 1.'de verilmiştir. Çizelge 1.'de 
görüleceği üzere Türkiye'de 1980 yılında 3,55 milyon olan isletme sayısı, genel tarım sayımlarına göre, 1990 y1lında 3,97 milyon, 2001 y1lında ise 3,02 milyon'dur.

Çizelgede de görüldüğü gibi işletmelerin büyük bir çoğunluğunu küçük işletmeler oluşturmasına rağmen, ișlenen arazilerin önemli bir bölümü orta ve büyük işletmeler tarafindan kullanılmaktadır. 1980 genel tarım sayımına göre işletmelerin \% 82'sini oluşturan 10 hektardan küçük işletmeler, 1990 genel tarım sayımında \% 85 ve 2001 genel tarım sayımında \%83'ünü oluşturmakta ve toplam alanın yaklaşık olarak 42'sini işlemektedirler. İşletme başına düşen ortalama parsel sayısı üç sayımda da 6'yı aşmaktadır.

Bütün bu özellikleri nedeniyle çoğu işletmelerde girdi kullanımı ve tarımsal teknoloji seviyesi yetersiz, traktör verimliliği düșük kalmaktadır. Ayrıca bu nedenle çiftçilerin büyük bir bölümü yeter seviyede gelir ve gelişmeye sahip olamamaktadır. Bu durum tarımın gelişmesini ve rekabet yeteneğini, arazilerin verimli olarak kullanılmasını, sonuç olarak tarımın milli gelire yeterli katkıda bulunmasını engellemeye devam etmektedir.

İşletmelerin büyütülmesi veya uygun biçime getirilmesi için bugüne kadar gerçekçi önlemlerin alındığı söylenemez. Ara ara yapılan çalıșmalar ise istenen düzeyde olmamıştır. Tarımsal işletmeler bu nedenle gittikçe küçülmüș ve ekonomik bir bütün olmaktan çıkmıștır. Küçülen arazi varlığı çoğu kez bir ailenin asgari geçim koşullarını yaratmada yetersiz kaldığından kırsal alandan kentlere göçler olmakta, orada kalan arazi ya terk edilmekte ve kullanılmamakta ya da başkaları tarafından işlenmektedir.

Aslan ve ark. (2007), Arazi toplulaștırma projelerinin irdelenmesine yönelik olarak çeşitli ölçülebilir parametreleri inceledikleri bir araştırmalarında; ortalama parsel büyüklüğü, parsel adedi, işletme başına ortalama parsel adedi, arazi toplulaştırma katsayısı ve indirgenme indeksini gösterge olarak kullanmışlardır.

Kuzey Vietnam'daki arazi parçalılı̆̆ının ekonomik etkileri Hung ve ark. (2007) tarafından incelenmiştir. Araştırıcılar, karşılaştırmalı üretici anketleri ve istatistiksel analizlerden sağladıkları veriler 1şığında, küçük işletmelerin büyük işletmelere oranla daha fazla parçalandığını ve bu parçalılığın verim ve girdi maliyetlerine negatif yönde etkilediğini saptamışlardır.

Köse (2009) tarafindan, Manisa'da uygulanan bir arazi toplulaștırma projesinde, aynı sekonderden su alan, toplulaştırılmıș ve toplulaştırılmamıș olmak üzere 2 farklı tersiyerdeki etkinliklerini ele alınmıştır. Çalışma kapsamında toplulaştırmalı ve toplulaştırmasız durumlar bazında tersiyerlerden su alan alanlardaki parsel adedi, şekil ve büyüklüğü, ulaşım ve sulama ağı, mülkiyet ve parçalılık durumu ile sulama oranı göstergeleri mukayese edilmiştir. Araştırmanın yürütülmesinde CBS'nden yararlanılmıştır. Çalışma neticesinde; toplulaştırılmış alanda sulama ağından direkt yararlanan parsel oranının \%60, toplulaştırılmamış alanda ise bu oranın \%18 olduğu ortaya çıkarılmıștır.

Hisseli satış, bilinçsiz kamulaştırma, miras paylaşımı vb. nedenlerle ortaya çıkan parçalanma, tarımsal işletmelerin ekonomik işletme büyüklüklerini kaybetmesine yol açmaktadır. Bu durum tarımsal faaliyetlerin uygun bir şekilde yapılmasını engellemekte ve verimliliği artırıcı tedbirlerin alınmasını da güçleştirmektedir (Yağanoğlu ve ark., 2000).

Çizelge 1. Türkiye'de tarım işletmelerinin ortalama büyüklüğü ve sayısı (Arıcı ve Akkaya Aslan 2010)

\begin{tabular}{|c|c|c|c|c|c|c|c|c|c|c|c|c|}
\hline \multirow{2}{*}{$\begin{array}{c}\text { İşletme } \\
\text { büyüklüğü } \\
\text { (ha) }\end{array}$} & \multicolumn{3}{|c|}{$\begin{array}{l}\text { İşletme sayısı } \\
\text { (1000 adet) }\end{array}$} & \multicolumn{3}{|c|}{$\begin{array}{c}\text { İşletme sayısı dağılımı } \\
(\%)\end{array}$} & \multicolumn{3}{|c|}{$\begin{array}{l}\text { İşletmelerin ortalama } \\
\text { büyüklüğü (ha) }\end{array}$} & \multicolumn{3}{|c|}{$\begin{array}{c}\text { Tarım alanlarının } \\
\text { dağılımı }\end{array}$} \\
\hline & 1980 & 1990 & 2001 & 1980 & 1990 & 2001 & 1980 & 1990 & 2001 & 1980 & 1990 & 2001 \\
\hline $0.1-1.9$ & 1011 & 1385 & 1008 & 28 & 35 & 33 & 1 & 1 & 1 & 4 & 6 & 5 \\
\hline $2.0-4.9$ & 1165 & 1275 & 951 & 33 & 32 & 31 & 3 & 3 & 3 & 16 & 17 & 16 \\
\hline $5.0-9.9$ & 738 & 713 & 560 & 21 & 18 & 19 & 7 & 7 & 7 & 21 & 19 & 21 \\
\hline Ara Top. & 2914 & 3373 & 2519 & 82 & 85 & 83 & - & - & - & 41 & 42 & 42 \\
\hline $10.0-19.9$ & 413 & 383 & 327 & 12 & 10 & 11 & 13 & 13 & 13 & 23 & 21 & 24 \\
\hline $20.0-49.9$ & 194 & 174 & 154 & 5 & 4 & 5 & 28 & 27 & 27 & 24 & 2 & 23 \\
\hline $50.0-<$ & 29 & 37 & 22 & 1 & 1 & 1 & 93 & 109 & 95 & 12 & 17 & 11 \\
\hline Ara Top. & 636 & 594 & 503 & 18 & 15 & 17 & - & - & - & 59 & 58 & 58 \\
\hline Toplam & 3550 & 3967 & 3022 & 100 & 100 & 100 & 6 & 5,9 & 6,1 & 100 & 100 & 100 \\
\hline
\end{tabular}


Dağınık ve parçalı yapıdaki parselleri birleştirmenin ve şekillerini düzeltmenin yanında, kırsal alan sosyo-ekonomik koşullarının iyileşmesini sağlayan arazi toplulaştırma, parçalanmış ve dağınık arazilerden oluşan işletmeler için adeta bir can simidi fonksiyonu görmektedir (Kirmikil ve ark., 2010).

$\mathrm{Bu}$ bağlamda ülkemizde tarım arazilerinin parçalanma durumu Çizelge 2'de verilmiştir. Çizelgeden görüldüğü gibi tarım işletmeleri genellikle çok parçalıdır. 2-3 parçaya ait işletme sayısı 1952 y1lında 515000,1980 yilında 930000,1990 yılında ise 1139000 'e yükselirken 2001 yılında 1119000 'e düştüğü gözlenmektedir. 6-9 ve 10 parçadan fazla işletmelerin sayısında 1980 yılında artış gözlenirken 1990 ve 2001 sayımlarında düşüş gözlenmektedir.

Avrupa Birliği (AB) ortalamasına göre toplam işletmelerin \% 30,8'ini, 10,0-49,9 hektar arası araziye sahip işletmeler oluşturmaktadır. Birliğin tarım sektörü yönünden en güçlü ülkeleri olan Hollanda'da $\% 53,1$, İngiltere'de $\% 42,2$, Fransa'da $\% 52,5$ ve Almanya'da \%45,8 oranında olan 10,0- 49,9 ha araziye sahip işletme varlıkları orta ve büyük çapta işletmelerin $\mathrm{AB}$ tarımsal üretiminde yaygınlığını ortaya koymaktadır. AB'de 50 ha ve üzeri araziye sahip işletmelerin oranı da ülkemize oranla oldukça fazladır. $\mathrm{AB}$ ortalaması $\% 6,7$ olan 50 ha ve üzeri araziye sahip işletme oranı, Türkiye'de sadece'\% $0,9^{\prime}$ a ulaşabilmiştir. 50 hektar ve daha fazla araziye sahip işletmeler Türkiye'de işlenen alanların \% 17,1 ini oluştururken, AB'de bu oran \% 44,1'i bulmaktadır. Toplam tarım alanının birlik üyelerinden Fransa'da \% 5,6's1, İngiltere'de \%1,8'i, Almanya'da \%13,3'ü 10 hektardan küçük işletmelere bırakılmışken Türkiye'de $\% 42,06$ 'sının bu tip işletmelere birakılması, Ülkemizde küçük işletmelerin yaygınlığının Avrupa'daki gelişmiş ülkelerden çok daha fazla olduğunu ortaya koymaktadır (Parlak, 2010).

Ülkemiz 25 milyon hektarlık tarım arazisine sahiptir. Halihazır şartlarda bu arazilerin 8,5 milyon ha'1 ekonomik olarak sulamaya müsait haldedir. 2011 yılı sonu verileri ışığında, halk sulamalarıyla birlikte yaklaşık 5,61 milyon ha alanın sulamaya açıldığ görülmüștür. $\mathrm{Bu}$ alanlarda sulama oranları \%20 ila $\% 80$ arasında seyrederken, sulama randimanı değerlerininse $\% 20$ ila $\% 85$ arasında değiştiği gözlenmiştir (Anonim, 2012).

$\mathrm{Bu}$ çalışmada; Aydın merkeze bağlı Kırklar, Alanlı, Gödrenli köyleri ve Dalama Beldesi ile Yenipazar'a bağlı Merkez, Çulhan, Dereköy, Alhan, ve Hamzabali köylerini kapsayan 9 yerleşim biriminde toplulaştırma öncesi ve sonrası parsel büyüklükleri, işletme başına düşen parsel sayısına, parsellerin hisselilik durumları ve ortalama parsel büyüklüğü değerleri incelenmiştir.

\section{MATERYAL ve YÖNTEM}

\section{Materyal}

Çalışma Aydın merkeze bağlı Alanlı, Kırklar, Gödrenli ve Dalama Beldesi ile Yenipazar'a bağlı Merkez, Alhan, Çulhan, Dereköy ve Hamzabali köylerini kapsayan 9 yerleşim biriminde toplam 4389 ha alanda yürütülmüştür.

\section{Araștırma alanının konumu}

Aydın İli; ülkemizin güneybatısında 37. ve 38 . kuzey enlemleri ile 27. ve 29. doğu boylamları arasındadır. Yüz ölçümü 800700 ha'dır. Toplam alanın \%45,3'ü olan 363215 ha'da tarım yapılmaktadır. Batısı Ege Denizi'ne açılan il, doğusunda Denizli, kuzeyinde Manisa ve İzmir, güneyinde ise Muğla illeri ile komşudur (Anonymous 2013).

\section{İklim özellikleri}

Bölgede Akdeniz iklimi hakimiyeti görülmektedir. Yıllık ortalama yağış miktarı 624,8 mm'dir. Bu miktar alt bölgeler arasında oldukça değişkenlik göstermekte olup yağış miktarının büyük kısmı kış (\% 44,5), sonbahar (\% 22,7) ve ilkbahar (\% $23,9)$ aylarında düşer. Yaz döneminde görülen ortalama yağış miktarı ise $\% 8,9^{\prime}$ dur. Uzun yıllara ait

Çizelge 2. Ülkemizde tarım arazilerinin parçalanma durumu (Arıcı ve Akkaya Aslan, 2010)

\begin{tabular}{|c|c|c|c|c|c|c|c|c|}
\hline \multirow{2}{*}{ Parça sayıs1 } & \multicolumn{2}{|c|}{1952} & \multicolumn{2}{|c|}{1980} & \multicolumn{2}{|c|}{1990} & \multicolumn{2}{|c|}{2001} \\
\hline & $\begin{array}{c}\text { İşletme } \\
\text { say1s1 } \\
\text { (1000 } \\
\text { adet) }\end{array}$ & $\begin{array}{c}\text { Dağllım } \\
(\%)\end{array}$ & $\begin{array}{c}\text { İşletme } \\
\text { say1s1 } \\
\text { (1000 } \\
\text { adet) }\end{array}$ & $\begin{array}{c}\text { Dağılım } \\
(\%)\end{array}$ & $\begin{array}{c}\text { İşletme } \\
\text { say1s1 } \\
\text { (1000 } \\
\text { adet) }\end{array}$ & $\begin{array}{c}\text { Dağılım } \\
(\%)\end{array}$ & $\begin{array}{c}\text { İşletme } \\
\text { say1s1 } \\
\text { (1000 } \\
\text { adet) }\end{array}$ & $\begin{array}{l}\text { Dağılım } \\
(\%)\end{array}$ \\
\hline 1 & 125 & 6 & 335 & 10 & 578 & 14 & 589 & 20 \\
\hline $2-3$ & 515 & 23 & 930 & 26 & 1.139 & 29 & 1119 & 37 \\
\hline $4-5$ & 525 & 23 & 795 & 22 & 904 & 23 & 614 & 20 \\
\hline $6-9$ & 596 & 26 & 790 & 22 & 760 & 19 & 485 & 16 \\
\hline $10+$ & 513 & 23 & 700 & 20 & 586 & 15 & 214 & 7 \\
\hline Toplam & 2274 & 100 & 3550 & 100 & 3967 & 100 & 3022 & 100 \\
\hline
\end{tabular}


iklim verileri Aydın Meteoroloji İl Müdürlüğü'nden temin edilmiş olup, araştırma alanına ait uzun yıllar aylık ortalama sıcaklık, aylık ortalama yağış ve aylık ortalama nispi nem miktarı değerleri Çizelge 3'de verilmiştir. Uzun yıllar ortalama sıcaklığı, şubat ayında 9.0 oC; Temmuz ayında ise 28.7 oC olarak tespit edilmiştir. Uzun yıllar ortalama nispi nem \% 61,4'dür (Anonim, 2014).

\section{Toprak özellikleri}

Aşağ1 Büyük Menderes havzasında 16 çeşit toprak grubu vardır. Sulu tarım yapılan ve sulanabilir arazilerin topraklarının yaklaşık \%60-70'ini alüvyal, \% 20-30'unu kolüvyal ve geri kalanını da kırmızı kestane, kahverengi orman, kalkersiz kahverengi ve kestane rengi topraklar oluşturur. Alüvyal topraklar taban arazileri oluştururlar. Profilleri derin ve her türlü bitkinin yetişmesine elverişli özellik göstermektedir. Havza toprakları ağırdan çok hafife kadar değişen çok çeşitli bünyelere sahiptir, ancak ovanın büyük bölümü orta bünyeli topraklardan oluşmaktadır (Akçay, 2007). Aydın ili toprak sinıflarına göre arazi kullanım durumu Çizelge 4'de verilmiştir (Anonim, 2013).

Çizelge 4'den izleneceği gibi, Aydın'da I.-IV. Sinıf tarım arazileri 231102 ha olup, VI.-VII. Sinıf arazilerin toplamı 164392 ha'dır. Tarım alanlarından sonra 2. sırayı alan orman ve fundalıklar VII. Sınıf arazi üzerinde yoğunlaşmıştır.

Çizelge 3. Araştırma alanına ait uzun yıllar ortalama iklim verileri

\begin{tabular}{|c|c|c|c|}
\hline AYLAR & $\begin{array}{c}\text { Uzun y1llar } \\
\text { ortalama } \\
\text { sicaklık } \\
\left({ }^{0} \mathrm{C}\right)\end{array}$ & $\begin{array}{c}\text { Uzun y1llar } \\
\text { ortalama } \\
\text { nispi nem } \\
(\%)\end{array}$ & $\begin{array}{c}\text { Uzun } \\
\text { yıllar } \\
\text { toplam yağış } \\
(\mathrm{mm})\end{array}$ \\
\hline OCAK & 8.3 & 70.7 & 99.7 \\
\hline ŞUBAT & 9.0 & 68.0 & 86.8 \\
\hline MART & 11.9 & 65.1 & 73.8 \\
\hline NISAN & 15.9 & 62.5 & 53.9 \\
\hline MAYIS & 21.1 & 56.4 & 36.2 \\
\hline HAZIRAN & 26.2 & 48.8 & 11.1 \\
\hline TEMMUZ & 28.7 & 49.5 & 4.8 \\
\hline AĞUSTOS & 27.7 & 54.3 & 4.5 \\
\hline EYLÜL & 23.2 & 56.6 & 13.7 \\
\hline EKİM & 18.7 & 62.8 & 41.1 \\
\hline KASIM & 13.1 & 68.9 & 92.6 \\
\hline ARALIK & 9.8 & 73.6 & 117.6 \\
\hline YILLIK ORT/TOPL & $\mathbf{1 7 . 8}$ & $\mathbf{6 1 . 4}$ & $\mathbf{6 2 4 . 9}$ \\
\hline
\end{tabular}

Çizelge 4. Aydın İli toprak sınıflarına göre arazi kullanım durumu (Anonim, 2013)

\begin{tabular}{|c|c|c|c|c|c|}
\hline \multirow{2}{*}{ TOPRAK SINIFLARI } & \multicolumn{5}{|c|}{ Toprak Sinıfına Dahil Alanlar ( ha ) } \\
\cline { 2 - 6 } & Ekilebilir Alan & Mera & Orman-Funda & Diğer & Toplam \\
\hline I.Sınıf & 54158 & 123 & - & 436 & 54717 \\
\hline II.Sınıf & 44464 & 956 & - & 564 & 45984 \\
\hline III.Sınıf & 74910 & 2684 & 3414 & 544 & 81552 \\
\hline IV.Sınıf & 57570 & 6614 & 11365 & 524 & 76073 \\
\hline V.Sınıf & - & - & - & -- & - \\
\hline VI.Sınıf & 54240 & 10665 & 59169 & 32715 & 156789 \\
\hline VII.Sınıf & 110152 & 26424 & 224052 & 35728 & 396356 \\
\hline VIII.Sınıf & - & - & - & 12326 & 12326 \\
\hline Su Yüzeyi & - & - & - & - & 8103 \\
\hline Genel Toplam & 395494 & 47466 & 298000 & 82837 & 831900 \\
\hline
\end{tabular}


Kullanma kabiliyet sınıfları 8 adet olup, toprak yarar ve sınırlandırmaları I. sınıftan VIII. Sınıfa doğru giderek artmaktadır.

SINIF I. : I. sınıf arazilerin kapladığı alan 54717 ha olup, il yüzölçümünün \% 7'sini teşkil etmektedir. Topoğrafyaları hemen hemen düzdür.

SINIF II. : II. Sınıf arazilerin kapladığı alan 45 984 ha olup, il yüzölçümünün \% 6'sını teşkil etmektedir. Hafif eğimli yapıda, idealden daha az toprak derinliği özellikleri ile kültür bitkileri, çayır, mera ve orman için kullanılabilir.

SINIF III. : $\mathrm{Bu}$ sinıftaki topraklar II. Sinıftakilerden daha fazla sinırlandırmalara sahiptir. III. Sınıf arazilerin kapladığı alan 81552 ha olup, il yüzölçümünün \% 10'una sahiptir.

SINIF IV. : IV. Sınıf arazilerin kapladığı alan 76 073 ha olup, il yüzölçümünün \% 9'una sahiptir. Bu sınıfta, toprakların kullanılmasındaki kisitlamalar III. Sınıftakinden daha fazla ve bitki seçimi daha sınırlıdır.

SINIF V. bulunmamaktadir.

SINIF VI. : İl yüzölçümünün \% 19'una tekabül eden 156789 ha,

SINIF VII. : İl yüzölçümünün \% 47'sine tekabül eden 396356 ha,

SINIF VIII. : İl yüzölçümünün \% 1'ine tekabül eden 12326 ha,
SU YÜZEYİ: İl yüzölçümünün \% 1'ine tekabül eden 8103 ha'lık bir alana sahiptir.

\section{Tarımsal özellikler}

Aydın ili arazi varlığı ve kültür arazilerinin kullanım durumu Çizelge 5 ve 6 'da verilmiştir. Aydın topraklarının \%47,54'ü olan 395494 ha alanda tarımsal üretim yapılmaktadır. Geriye kalan arazilerin 314732 ha orman, 25242 ha'ı çayır-mera, 14271 ha'ı göl ve bataklık ve 82161 ha ise tarım dışıdır.

Çizelge 6'dan de izleneceği gibi en geniş alanı zeytin ve meyvelikler kaplamaktadır. Pamuk girdi maliyetlerinin aşırı yükselmesi ve satış fiyatının bunu karşılamaması sonucu sanayi bitkileri ekilişleri 109 000 ha'dan 58638 ha'a gerilemiştir. Sebze ekim alanları ise 11446 ha dolaylarındadır.

Aydın ilinde sulanan alanlar Çizelge 7'de verilmiştir. Çizelgeden de izleneceği gibi, sulanan alanların \% 62'si devlet sulaması; \% 24'ü halk sulamasıdır. Sulanmayan alan oranı ise \% 14'dür. Aydın ilinde sulama genelde devlet sulaması (DSİ, mülga KHGM ) şeklinde olup, DSİ sulama ile ilgili işletme haklarını Sulama Birliklerine devretmiştir. Halk sulaması yeraltı sulaması olarak yapılmakta olup, devlet sulamasindan azdir.

Çizelge 5. Aydın İli arazi varlığı (Anonim, 2013)

\begin{tabular}{|c|c|c|}
\hline Arazi kullanım şekli & Alan (ha) & $\%$ \\
\hline Kültür Arazisi & 395494 & 47,54 \\
\hline Çayır Mera Arazisi & 25242 & 3,03 \\
\hline Orman & 314732 & 37,83 \\
\hline Göl-Bataklık & 14271 & 1,72 \\
\hline Tarım Dışı Araziler & 82161 & 9,88 \\
\hline TOPLAM & $\mathbf{8 3 1} \mathbf{9 0 0}$ & $\mathbf{1 0 0 , 0 0}$ \\
\hline
\end{tabular}

Çizelge 6. Aydın İli kültür arazilerinin kullanımı (Anonim, 2013)

\begin{tabular}{|c|c|c|c|}
\hline Arazi kullanımı & Alan (ha) & Kültür arazisine oran (\%) & Toplam alana oran (\%) \\
\hline Zeytin ve Meyvelik & 212255 & 53,7 & 25,51 \\
\hline Sanayi Bitkileri & 58638 & 14,8 & 7,04 \\
\hline Hububat & 50715 & 12,8 & 6,10 \\
\hline Sebze Alanları & 11446 & 2,9 & 1,37 \\
\hline Yem Bitkileri & 33839 & 8,6 & 4,06 \\
\hline Turunçgiller & 5374 & 1,4 & 0,64 \\
\hline Bağ & 1875 & 0,5 & 0,02 \\
\hline Diğer Alanlar & 21352 & 5,4 & 2,56 \\
\hline TOPLAM & $\mathbf{3 9 5 4 9 4}$ & $\mathbf{1 0 0 , 0 0}$ & 47,3 \\
\hline
\end{tabular}

Çizelge 7. Devlet Su İşleri (DSİ), KHGM(mülga) ve halk tarafından sulanan alanların dağılımı (Anonim, 2013)

\begin{tabular}{|c|c|}
\hline Kurum Ad 1 & Sulanan Alan ( ha ) \\
\hline DSI & 147341 \\
\hline KHGM (mülga) & 6079 \\
\hline Halk Sulaması & 60771 \\
\hline Toprak Su Kooperatifi Sulamaları & 2198 \\
\hline TOPLAM & $\mathbf{2 1 6 ~ 3 8 9}$ \\
\hline
\end{tabular}




\section{Yöntem}

Aydın merkeze bağlı Alanlı, Kırklar, Gödrenli ve Dalama Beldesi ile Yenipazar'a bağlı Merkez, Alhan, Çulhan, Dereköy ve Hamzabali köylerini kapsayan 9 yerleşim biriminde toplam 4389 ha alanda arazi toplulaştırma projesi tamamlanmıștır. Ele alınan proje kapsamında da arazi toplulaştırma çalışmalarının uygulanması amacıyla Coğrafi Bilgi Sistemi destekli bilgisayar programlarından Netcad paket programı ve Nettop arazi toplulaştırma yazılımı kullanılmıștır. Program, Tarım Reformu Genel Müdürlüğü'nün desteği ile geliştirilmiş olup Arazi Toplulaştırması Teknik Talimatı çerçevesinde toplulaştırma projeleri yapmaya olanak sağlamaktadır. Bu programlar arasında öne çıkan Netcad, Tarım Reformu Genel Müdürlüğü ve özel sektör tarafından da yaygın olarak kullanılmaktadir Nettop Arazi Toplulastırma Yazılımı'nda mevcut bulunan bir kadastro haritasının sayısallastırılması, ilgili kadastro parsellerinin kimlere ait olduğunun Nettop Arazi Toplulastırma Modülüne tanıtılması, yeni blok planının yapılması, daha sonrasında ise Tarım Reformu Genel Müdürlüğü Arazi Toplulaştırması Teknik Talimatı uyarınca ilgili proje sahası için gerekli endeks puanlarının hesaplanması işlemleri yapılmaktadır. Endeks hesapları yapıldıktan sonra ise çiftçilerden yeni parselleri için blok tercihleri alınmakta ve bu tercihler Netcad ortamına aktarılmaktadır. Sonrasında ise bu tercihlere göre yeni parsellerin dağıtımları yapılmakta ve isteğe bağlı olarak toplulaştırma raporları ve tapular çıktı olarak alınabilmektedir (Itır, 2013).

Öncelikle toplulaştırmasız durumu gösteren 1/5000 ölçekli proje ile eski kadostro paftası Netcad ortamında sayısallaştırılmıştır. Sayısallaştırılmış paftalar kullanılarak toplulaştırılmasız haldeki sulama kanallarının doğrudan sulayacağı parsel sayısı, sulama oranları ve parsel şekillerine ilişkin bilgiler belirlenmiştir.

Daha sonra proje sahasına ilişkin toplulaştırma projesinde Netcad tabanlı 1/5000-1/25000 ölçekli haritalar üzerinde tarla içi yollar, sulama kanalları, drenaj kanalları, blokların ve parsellerin konum ve büyüklükleri gösterilmiştir. Sonuçta elde edilen haritalardan faydalanarak toplulaştırma öncesi ve sonrası, parsel sayıları, hisseli parsel durumları ve ortalama parsel büyüklüğü değerlendirilmiştir.

\section{BULGULAR ve TARTIŞMA}

Proje sahasında parsel büyüklüklerinin değerlendirilmesi

Türkiye'de arazi toplulaştırmasını gerektiren en önemli etkenlerden birisi de arazi parçalılığıdır. Türkiye'deki işletmelerin büyüklükleri, gerekli genişliğe sahip değildir. Üretici bazındaki işletmelerin üretim faaliyeti yürüttükleri arazi miktarı; birbirinden uzak ve sınırlı ve bunun yanında çok sayıda parçadan oluştuğu için de için de, bu araziler üzerinde istikrarlı işletmeler inşa edilememekte ve halihazırdaki durumlarıyla da beklenen üretim performansını yakalayamamaktadırlar (Ballı 2005).

Çalışma alanında toplulaştırma öncesi ve sonrası parsel büyüklüklerine ve toplam alan içindeki oranlarına göre dağılımı Çizelge 8'de verilmiştir. Araştırma alanına ait çizelgeden de anlaşılacağı üzere arazi toplulaştırması yapılan alan toplam 43890 dekar olup toplam parsel sayıs1 ise 8465 'dir. Arazi toplulaştırması öncesinde 0-4,99 dekar arasında alana sahip parsel sayısı 5 513; 5-9,99 dekar arasında alana sahip parsel say1s1 ise 2 038'dir. Bu parsellerin kapladıkları toplam alanlar ise sirasıyla 12241 dekar ve 14033 dekardır. Buradan da görüldüğü gibi proje sahas1 arazileri 0-4,99 ile 5-9,99 da arasinda yoğunlaşmış olup toplam parsel sayılarına oranlandığında bu oranlar sirasiyla $\% 65$ ve $\% 24$ olarak belirlenmiştir. Toplulaştırma öncesi 10 dekardan büyük parsel sayıları 729 ve 185 olarak belirlenirken bunların kapladıkları alanlar ise sırasıyla 9561 da-8 055 da arasındadır. Yine aynı çizelgeden toplulaştırma sonrası parsel büyüklükleri incelemesinde toplam parsel say1s1 4 731, parsellerin toplam alanı ise 41730 dekardır. 0-4,99 dekar arasında alana sahip parsel sayıs1 1955 , toplam parsel sayısına oranı ise \%41; alan olarak ise 5905 dekardır. Diğer taraftan parsellerin \% 32'si 5-9,99 dekar büyüklüğünde olup toplam kapadıkları alan ise 11126 dekardır. 10 dekar üzerindeki parsel sayıları oranı ise yaklaşık \%25 dolayındadır. Buradan da görüldüğü gibi parsellerin büyük bir kısmı gerek alan gerekse sayı olarak 0-9,99 dekar grubunda toplanmıștır.

Özer (2010)'da Çanakkale-Biga ilçesinde arazi toplulaştırmasının etkinliğini saptamak amacıyla yürüttüğü araştırmada; toplulaştırmanın ulașım ve sulama etkinliği, parsel şekil, büyüklük ve sayısına etkilerini incelemiş ve arazi toplulaştırma ile birlikte toplam parsel adedinde \%63'lük bir azalma meydana geldiğini ve sulama oranının da \%81,6 olarak gerçekleştiğini ortaya çıkarmıştır.

Sarımsaklı Köyünde gerçekleştirilen arazi toplulaştırma projesi öncesinde ve sonrasındaki parsel şekillerinin durumu karşılaştırıldığında; parçalı ve dağınık halde bulunan işletme parsellerinin birleştirilerek, toplam parsel sayısının proje öncesine göre \%23 oranında azaldığı görülmüştür. Yeni mülkiyet haritasında toplamda 292 adet parsel oluşturulmuştur Parçalı ve farklı mevkilerde bulunan dağınık haldeki parsellerin birleştirilmesi ile parsellerin yüzölçümleri de artış göstermiştir. Örneğin, proje öncesinde 5 dekardan küçük 109 adet parsel bulunurken, bu say1 proje sonrasinda 53'e düşmüştür (Itır, 2013).

Çelebi (2010) yürütmüş olduğu bir araştırmada, Karaman'da sürdürülen bazı toplulaștırmalardaki toplam parsel adedi, malik başına düşen parsel adedi ve miras yoluyla oluşan hisselendirmeler, sulama ve ulaşım hattından direkt olarak yararlanan parsel adetleri, ulaşım ve sulama sistemi uzunlukları ve sınır kayıplarıyla ilgili arazi toplulaştırması öncesi ve 
sonrası veriler kıyaslanmış ve arazi toplulaştırma sonrası ulaşım ve sulama hatlarından direkt yararlanan parsel oranının \%100'e yükseldiği saptanmıştır.

Proje sahasinda hisseli parsellerin değerlendirilmesi

Araştırma alanında, toplulaștırmadan önce ve sonraki hisseli parsellerin değișimi, oranları ve hisseli parsellerin alan dağılımlarına ilişkin veriler Çizelge 9 ve Çizelge 10'da verilmiştir.

Çizelge 9'dan da görüleceği gibi toplulaştırma öncesi proje alanında toplam 8465 adet parsel bulunmaktadır. Proje sonrasında ise bu değer 4731 olmuş ve toplam parsel sayısındaki azalma oranı $\% 44$ olmuştur. Parsellerdeki hisselilik durumları 1-4 hisse ve $>4$ hisse arasında değişmektedir. Proje sahasında hisselilik durumu 1 ve 2 hisse arasında yoğunluk göstermiştir. Tek kişiye ait parsel sayısı en yüksek Yenipazar, Hamzabali ve Dalama birimlerinde bulunmaktadır.

Çizelge 10 incelendiğinde; toplulaştırma öncesinde ve sonrasında tek kişiye ait parsel oranları en yüksek değer almıștır. 9 yerleșim biriminde bu değerler \%77,97-\%93,11 arasında değişmiştir. Diğer taraftan iki kişiye ait parsellerin hisselilik oranları ise $\% 3,81$ - \%14,04 arasında bulunmuştur. Proje sahasında 3 ve daha fazla kișiye ait hisselilik oranları ise $\% 0,44-\% 6,86$ arasındadır. Genel olarak yukarıdaki çizelgelere bakıldığında ve araștırma birimlerindeki şahıs parsellerinin mülkiyet dağılımı incelendiğinde, toplulaştırma öncesi \%84,34 orana sahip tek hisseli parseller, toplulaştırma sonras1 \% $\% 5,34$ 'e yükselmiştir. Proje sahasındaki arazilerin 1-2 kişiye ait olması mülkiyet sorununun olmadığını; ancak parsellerin dağınık ve ekonomik anlamda tarım yapamayacak şekilde küçük olması temel sorun olarak görülmektedir.

Arazi toplulaştırması ile parsellerdeki hisse durumları asgariye inmekte ve parsel alanları büyümekte olup bu da modern tarım olanaklarını artırmakta ve meydana gelebilecek hukuksal sorunları da ortadan kaldırmaktadır. Benzer șekilde Çelebi (2010); parsel-hisse değerlerini sirasiyla KonyaÇumra KOS-6'da toplulaştırmadan önce 2 131, toplulaştırmadan sonra 1360 ; Konya-KaramanYuvatepe'de toplulaştırmadan önce 497 , toplulaştırmadan sonra 283; Konya -KaramanBölükyazı'da toplulaştırmadan önce 378 , toplulaştırmadan sonra 318; Konya-SeydişehirAkçalar'da toplulaştırmadan önce 7279 , toplulaştırmadan sonra 1 661; Konya-IlgınBoğazkent'de toplulaştırmadan önce 740 , toplulaştırmadan sonra 287; Karaman-MerkezKilbasan'da toplulaştırmadan önce 1951 , toplulaştırmadan sonra 1 086; Karaman-MerkezBeydilli de toplulaştırmadan önce 1613 , toplulaştırmadan sonra 607 olarak belirlemiştir. Bu sonuçlar araştırma bulguları ile benzerlik göstermektedir.

Türkiye'deki toplulaştırmalarda genellikle istenilen başarının sağlanamadığı konuların başında her işletmenin tek bir parsele kavuşturulamaması konusu gelmektedir. Çizelge 10 (devam)'da görüldüğü gibi, Alanlı, Gödrenli, Kırklar ve Dalama köylerinde toplulaştırma sonrası tek hisseli parsel sayıları toplulaştırma öncesi hisseli parsel sayılarından fazla çıkmıştır. Bu durum, aynı işletme içerisinde eșler üzerine kayıtlı parsellerin toplulaştırma sonrası da hisselik durumlarının devam etmesiyle açıklanabilir. Toplulaştırmalarda muvafakat safhasında karşılaşılan güçlükler uygulamada çiftçilerin uygun olmayan taleplerinin yerine getirilmesi sonucunu doğurmakta, bu da yeterli düzeyde bir toplulaştırmayı engellemektedir. Karaman Bölükyazı ve Beydilli ile Seydişehir Akçalar'da toplulaştırmadan sonra da yüksek oranda görülen hisse sayıları bu durumun bir sonucudur. Bu nedenle özellikle devlet yatırımı olan yerlerde toplulaştırma zorunlu olmalı ve muvafakat gerekmemelidir (Çelebi, 2010).

Proje Sahasında Parsel Sayısı Ve Ortalama Parsel Büyüklüğünün Değerlendirilmesi

Proje sahasına ilișkin parsel sayıları ve ortalama parsel büyüklüklerine ait veriler Çizelge 11 'de verilmiştir. Çizelge 11'de görüleceği gibi proje sahasında toplam işletme sayısı 5454 iken, ortalama işletme büyüklüğü 8,05 da olarak belirlenmiștir. Her bir işletme tek tek ele alındığında, beher işletmede yer alan ortalama parsel adedi toplulaştırma öncesi 1,55 iken; toplulaştırma sonrası 0,87 olarak gerçekleşmiş ve azalma oranı \% 178,93 olmuştur. Diğer taraftan proje sahası ortalama parsel alanlarına bakıldığında; toplulaştırma öncesi 5,18 da olan ortalama parsel alanı toplulaştırma sonrası 9,28 da'a yükselmiş ve artma oranı \% 1,79 olarak belirlenmiştir. Çizelgeye genel olarak bakıldığında tüm yerleşim birimlerinde toplulaştırmadan sonra parsel sayıları azalmış, ortalama parsel büyüklükleri ise artmıştır. Bu durum; arazi toplulaştırması yapılırken derecelendirme işleminin doğru bir şekilde yapıldığı; yol, sulama ve drenaj hizmetlerinin ihtiyaçlara cevap verecek derecede gerçekleștiği ve işletme sahipleriyle yapılan mülakatlarda arazi sahiplerinin istekleri ön planda tutulmak kaydıyla arazi dağıtım işlemlerinin planlanan seviyede yapılması ile açıklanabilir.

Sinop Boyabat Durağan Katılımcı Arazi Toplulaştırma Projesinin tümü incelendiğinde Kayaboğazı, Yabanlı ve Yalnızkavak köylerinin ortalama parsel büyüklüğü Cemalettin Köyünden fazla, ortalama parsel büyüklüğü 7 dekarın altındadır. Diğer 14 köy ve ilçe merkezi ortama parsel büyüklüğü, 2 dekarın altına olan yerler bile olup, Cemalettin Köyü ortalama parsel büyüklügüünden azdır (Abacı, 2009). Cemalettin köyü' bakıldığında toplulaştırmadan önce parsel sayısı 2373 iken toplulaştırmayla beraber bu değer 545 'e düşmüştür. Ortalama parsel büyüklüğü ise 1,37 da'dan 5,53 da'a yükselmiştir (Kır, 2012).

Konya Çumra Karkın köyünde arazi toplulaştırma projesinin uygulanmasından sonra 
mevcut parsel sayısının 890'dan 496'ya düştüğü ve böylece parsel sayısında \% 44 oranında azalma sağlanmıştır (Çevik, 1974). Yine aynı şekilde Konya Çumra Satır köyünde arazi toplulaştırması öncesinde 448 parsel var iken arazi toplulaştırması sonrasında 163 parsele düşmüştür (Çay ve ark., 2005). Orhaniye,
Dedemoğlu ve Alemdar köylerinde yapılan anket sonuçlarına göre; yapılan anketlerin \% 90'ında yeni mülkiyete itiraz edilmemiş toplulaştırmadan memnun kalınmıştır. Toplulaştırmadan sonra verim durumunda \% 100'ün üzerinde artış sağlanmıştır (Çay ve İşcan, 2002).

Çizelge 8. Toplulaştırma öncesi ve sonrası işletme büyüklüklerinin dağılımı

\begin{tabular}{|c|c|c|c|c|c|c|c|c|c|}
\hline \multirow[t]{2}{*}{ Birim adı } & \multirow{2}{*}{$\begin{array}{c}\text { Alan } \\
\text { aralığ } 1 \\
\text { (da) }\end{array}$} & \multicolumn{4}{|c|}{ ATPÖ } & \multicolumn{4}{|c|}{ ATPS } \\
\hline & & $0-4,99$ & $5-9,99$ & $10-19,99$ & $20>$ & $0-4,99$ & $5-9,99$ & $10-19,99$ & $20>$ \\
\hline \multirow[t]{4}{*}{ Yenipazar } & Adet & 858 & 514 & 237 & 57 & 421 & 404 & 250 & 99 \\
\hline & Adet $\%$ & 15,56 & 25,22 & 32,51 & 30,81 & 21,53 & 25,88 & 28,51 & 29,29 \\
\hline & Alan & 2396 & 3613 & 3149 & 2219 & 1286 & 2838 & 3475 & 3308 \\
\hline & Alan \% & 18,52 & 25,75 & 32,94 & 27,55 & 21,78 & 25,51 & 28,62 & 26,34 \\
\hline \multirow[t]{4}{*}{ Alhan } & Adet & 598 & 193 & 42 & 13 & 231 & 152 & 77 & 15 \\
\hline & Adet $\%$ & 10,84 & 9,47 & 5,76 & 7,03 & 11,82 & 9,74 & 8,78 & 4,44 \\
\hline & Alan & 1390 & 1310 & 551 & 359 & 665 & 1055 & 1024 & 458 \\
\hline & Alan \% & 10,75 & 9,34 & 5,76 & 4,46 & 11,26 & 9,48 & 8,43 & 3,65 \\
\hline \multirow[t]{4}{*}{ Çulhan } & Adet & 679 & 202 & 58 & 9 & 255 & 178 & 82 & 19 \\
\hline & Adet $\%$ & 12,31 & 9,91 & 7,96 & 4,86 & 13,04 & 11,40 & 9,35 & 5,62 \\
\hline & Alan & 1440 & 1389 & 749 & 222 & 730 & 1303 & 1097 & 513 \\
\hline & Alan \% & 11,13 & 9,90 & 7,83 & 2,76 & 12,36 & 11,71 & 9,04 & 4,09 \\
\hline \multirow[t]{4}{*}{ Dereköy } & Adet & 516 & 158 & 59 & 13 & 196 & 146 & 54 & 22 \\
\hline & Adet $\%$ & 9,35 & 7,75 & 8,09 & 7,03 & 10,03 & 9,35 & 6,16 & 6,51 \\
\hline & Alan & 1081 & 1047 & 768 & 761 & 605 & 1039 & 736 & 1098 \\
\hline & Alan \% & 8,36 & 7,46 & 8,03 & 9,45 & 10,25 & 9,34 & 6,06 & 8,74 \\
\hline \multirow[t]{4}{*}{ Hamzabali } & Adet & 683 & 380 & 119 & 33 & 330 & 255 & 149 & 58 \\
\hline & Adet $\%$ & 12,38 & 18,65 & 16,32 & 17,84 & 16,88 & 16,34 & 16,99 & 17,16 \\
\hline & Alan & 2450 & 2581 & 1534 & 1376 & 1015 & 1829 & 2066 & 2114 \\
\hline & Alan \% & 18,94 & 18,39 & 16,04 & 17,08 & 17,19 & 16,44 & 17,02 & 16,84 \\
\hline \multirow[t]{4}{*}{ Alanlı } & Adet & 339 & 144 & 38 & 8 & 130 & 107 & 59 & 19 \\
\hline & Adet $\%$ & 6,15 & 7,07 & 5,21 & 4,32 & 6,65 & 6,85 & 6,73 & 5,62 \\
\hline & Alan & 1016 & 989 & 502 & 369 & 427 & 759 & 814 & 723 \\
\hline & Alan \% & 7,86 & 7,05 & 5,25 & 4,58 & 7,23 & 6,82 & 6,70 & 5,76 \\
\hline \multirow[t]{4}{*}{ Gödrenli } & Adet & 337 & 159 & 46 & 9 & 122 & 94 & 64 & 26 \\
\hline & $\begin{array}{l}\text { Adet } \\
\%\end{array}$ & 6,11 & 7,81 & 6,31 & 4,86 & 6,24 & 6,02 & 7,3 & 7,69 \\
\hline & Alan & 847 & 1110 & 595 & 475 & 355 & 679 & 876 & 998 \\
\hline & $\begin{array}{l}\text { Alan } \\
\%\end{array}$ & 6,55 & 7,91 & 6,23 & 5,89 & 6,02 & 6,11 & 7,21 & 7,95 \\
\hline \multirow[t]{4}{*}{ Kırklar } & Adet & 396 & 129 & 47 & 12 & 103 & 94 & 62 & 22 \\
\hline & $\begin{array}{l}\text { Adet } \\
\%\end{array}$ & 7,18 & 6,33 & 6,45 & 6,49 & 5,27 & 6,02 & 7,07 & 6,51 \\
\hline & Alan & 860 & 883 & 600 & 622 & 325 & 682 & 869 & 908 \\
\hline & $\begin{array}{l}\text { Alan } \\
\%\end{array}$ & 6,65 & 6,29 & 6,28 & 7,72 & 5,50 & 6,13 & 7,16 & 7,23 \\
\hline \multirow[t]{4}{*}{ Dalama } & Adet & 739 & 159 & 83 & 31 & 167 & 131 & 80 & 58 \\
\hline & $\begin{array}{l}\text { Adet } \\
\%\end{array}$ & 13,40 & 7,80 & 11,39 & 16,76 & 8,54 & 8,39 & 9,12 & 17,16 \\
\hline & Alan & 1454 & 1111 & 1113 & 1652 & 497 & 942 & 1184 & 2437 \\
\hline & $\begin{array}{l}\text { Alan } \\
\%\end{array}$ & 11,24 & 7,92 & 11,64 & 20,51 & 8,42 & 8,47 & 9,75 & 19,41 \\
\hline \multirow[t]{2}{*}{ Toplam } & Adet & 5513 & 2038 & 729 & 185 & 1955 & 1561 & 877 & 338 \\
\hline & Alan & 12241 & 14033 & 9561 & 8055 & 5905 & 11126 & 12141 & 12557 \\
\hline
\end{tabular}


Çizelge 9. Toplulaştırma öncesi ve sonrası parsellerin hisselik durumu değerleri

\begin{tabular}{|l|l|l|l|l|l|l|l|l|l|l|}
\hline $\begin{array}{c}\text { Yerleşim } \\
\text { birimi }\end{array}$ & \multicolumn{2}{|c|}{ Yenipazar } & \multicolumn{2}{c|}{ Alhan } & \multicolumn{2}{c|}{ Çulhan } & \multicolumn{2}{c|}{ Dereköy Hamzabali } \\
\hline $\begin{array}{c}\text { Hisse } \\
\text { say1s1 }\end{array}$ & $\begin{array}{c}\text { ATPÖ } \\
\text { (adet) }\end{array}$ & $\begin{array}{c}\text { ATPS } \\
\text { (adet) }\end{array}$ & $\begin{array}{c}\text { ATPÖ } \\
\text { (adet) }\end{array}$ & $\begin{array}{c}\text { ATPS } \\
\text { (adet) }\end{array}$ & $\begin{array}{c}\text { ATPÖ } \\
\text { (adet) }\end{array}$ & $\begin{array}{c}\text { ATPS } \\
\text { (adet) }\end{array}$ & $\begin{array}{c}\text { ATPÖ } \\
\text { (adet) }\end{array}$ & $\begin{array}{c}\text { ATPS } \\
\text { (adet) }\end{array}$ & $\begin{array}{c}\text { ATPÖ } \\
\text { (adet) }\end{array}$ & $\begin{array}{c}\text { ATPS } \\
\text { (adet) }\end{array}$ \\
\hline 1 Hisse & 1299 & 1012 & 761 & 446 & 811 & 482 & 643 & 368 & 1231 & 716 \\
\hline 2 Hisse & 172 & 79 & 55 & 17 & 82 & 28 & 54 & 23 & 117 & 36 \\
\hline 3 Hisse & 85 & 33 & 13 & 10 & 31 & 11 & 23 & 14 & 34 & 15 \\
\hline 4 Hisse & 47 & 19 & 8 & 2 & 6 & 2 & 11 & 5 & 25 & 12 \\
\hline$>$ 4 Hisse & 63 & 29 & 9 & 4 & 18 & 15 & 15 & 12 & 80 & 25 \\
\hline $\begin{array}{l}\text { Parsel } \\
\text { say1s1 } \\
\text { (adet) }\end{array}$ & $\mathbf{1 6 6 6}$ & $\mathbf{1 1 7 2}$ & $\mathbf{8 4 6}$ & $\mathbf{4 7 9}$ & $\mathbf{9 4 8}$ & $\mathbf{5 3 8}$ & $\mathbf{7 4 6}$ & $\mathbf{4 2 2}$ & $\mathbf{1 4 8 7}$ & $\mathbf{8 0 4}$ \\
\hline
\end{tabular}

Çizelge 9. Toplulaştırma öncesi ve sonrası parsellerin hisselik durumu değerleri (devamı)

\begin{tabular}{|l|l|l|l|l|l|l|l|l|}
\hline \multicolumn{1}{|c|}{$\begin{array}{c}\text { Yerleşim } \\
\text { birimi }\end{array}$} & \multicolumn{2}{|c|}{ Alanlı } & \multicolumn{2}{c|}{ Gödrenli } & \multicolumn{2}{c|}{ Dirklar } \\
\hline Hisse say1s1 & $\begin{array}{c}\text { ATPÖ } \\
\text { (adet) }\end{array}$ & $\begin{array}{c}\text { ATPS } \\
\text { (adet) }\end{array}$ & $\begin{array}{c}\text { ATPÖ } \\
\text { (adet) }\end{array}$ & $\begin{array}{c}\text { ATPS } \\
\text { (adet) }\end{array}$ & $\begin{array}{c}\text { ATPÖ } \\
\text { (adet) }\end{array}$ & $\begin{array}{c}\text { ATPS } \\
\text { (adet) }\end{array}$ & $\begin{array}{c}\text { ATPÖ } \\
\text { (adet) }\end{array}$ & $\begin{array}{c}\text { ATPS } \\
\text { (adet) }\end{array}$ \\
\hline 1 Hisse & 464 & 241 & 462 & 259 & 519 & 236 & 898 & 320 \\
\hline 2 Hisse & 30 & 35 & 50 & 31 & 27 & 17 & 63 & 59 \\
\hline 3 Hisse & 20 & 21 & 17 & 6 & 14 & 12 & 54 & 15 \\
\hline 4 Hisse & 9 & 6 & 12 & 6 & 10 & 4 & 31 & 9 \\
\hline$>$ 4 Hisse & 6 & 3 & 10 & 9 & 14 & 10 & 62 & 17 \\
\hline $\begin{array}{l}\text { Parsel say1s1 } \\
\text { (adet) }\end{array}$ & $\mathbf{5 2 9}$ & $\mathbf{3 0 6}$ & $\mathbf{5 5 1}$ & $\mathbf{3 1 1}$ & $\mathbf{5 8 4}$ & $\mathbf{2 7 9}$ & $\mathbf{1 1 0 8}$ & $\mathbf{4 2 0}$ \\
\hline
\end{tabular}

Çizelge 10. Toplulaştırma öncesi ve sonrası parsellerinin hisselik durumu oranları

\begin{tabular}{|l|c|l|l|l|l|l|l|l|l|l|}
\hline $\begin{array}{c}\text { Yerleşim } \\
\text { birimi }\end{array}$ & \multicolumn{3}{|c|}{ Yenipazar } & \multicolumn{2}{c|}{ Alhan } & \multicolumn{2}{c|}{ Çulhan } & \multicolumn{2}{c|}{ Dereköy } & \multicolumn{2}{c|}{ Hamzabali } \\
\hline Hisse say1s1 & $\begin{array}{c}\text { ATPÖ } \\
(\%)\end{array}$ & $\begin{array}{c}\text { ATPS } \\
(\%)\end{array}$ & $\begin{array}{c}\text { ATPÖ } \\
(\%)\end{array}$ & $\begin{array}{c}\text { ATPS } \\
(\%)\end{array}$ & $\begin{array}{c}\text { ATPÖ } \\
(\%)\end{array}$ & $\begin{array}{c}\text { ATPS } \\
(\%)\end{array}$ & $\begin{array}{c}\text { ATPÖ } \\
(\%)\end{array}$ & $\begin{array}{c}\text { ATPS } \\
(\%)\end{array}$ & $\begin{array}{c}\text { ATPÖ } \\
(\%)\end{array}$ & $\begin{array}{c}\text { ATPS } \\
(\%)\end{array}$ \\
\hline 1 Hisse & 77,97 & 86,34 & 89,95 & 93,11 & 85,54 & 89,59 & 86,19 & 87,20 & 82,78 & 89,05 \\
\hline 2 Hisse & 10,32 & 6,74 & 6,50 & 3,81 & 8,64 & 5,20 & 7,23 & 5,45 & 7,86 & 4,47 \\
\hline 3 Hisse & 5,10 & 2,81 & 1,53 & 2,24 & 3,27 & 2,04 & 3,08 & 3,31 & 2,28 & 1,86 \\
\hline 4 Hisse & 2,82 & 1,62 & 0,94 & 0,44 & 0,63 & 0,37 & 1,47 & 1,18 & 1,68 & 1,49 \\
\hline$>$ 4 Hisse & 3,78 & 2,47 & 1,06 & 0,89 & 1,89 & 2,78 & 2,01 & 2,84 & 5,37 & 3,10 \\
\hline $\begin{array}{l}\text { Parsel say1s1 } \\
\text { (adet) }\end{array}$ & $\mathbf{1 ~ 6 6 6}$ & $\mathbf{1} \mathbf{1 7 2}$ & $\mathbf{8 4 6}$ & $\mathbf{4 7 9}$ & $\mathbf{9 4 8}$ & $\mathbf{5 3 8}$ & $\mathbf{7 4 6}$ & $\mathbf{4 2 2}$ & $\mathbf{1 4 8 7}$ & $\mathbf{8 0 4}$ \\
\hline
\end{tabular}

Çizelge 10. Toplulaştırma öncesi ve sonrası parsellerinin hisselik durumu oranları (devamı)

\begin{tabular}{|l|l|l|l|l|l|l|l|l|}
\hline $\begin{array}{c}\text { Yerleşim } \\
\text { birimi }\end{array}$ & \multicolumn{2}{|c|}{ Alanl1 } & \multicolumn{2}{c|}{ Gödrenli } & \multicolumn{2}{c|}{ Kırklar } & \multicolumn{2}{c|}{ Dalama } \\
\hline Hisse say1s1 & $\begin{array}{c}\text { ATPÖ } \\
(\%)\end{array}$ & $\begin{array}{c}\text { ATPS } \\
(\%)\end{array}$ & $\begin{array}{c}\text { ATPÖ } \\
(\%)\end{array}$ & $\begin{array}{c}\text { ATPS } \\
(\%)\end{array}$ & $\begin{array}{c}\text { ATPÖ } \\
(\%)\end{array}$ & $\begin{array}{c}\text { ATPS } \\
(\%)\end{array}$ & $\begin{array}{c}\text { ATPÖ } \\
(\%)\end{array}$ & $\begin{array}{c}\text { ATPS } \\
(\%)\end{array}$ \\
\hline 1 Hisse & 87,71 & 78,75 & 83,84 & 83,27 & 88,87 & 84,58 & 81,04 & 76,19 \\
\hline 2 Hisse & 5,67 & 11,43 & 9,07 & 9,96 & 4,62 & 6,09 & 5,68 & 14,04 \\
\hline 3 Hisse & 3,78 & 6,86 & 3,08 & 1,92 & 2,40 & 4,30 & 4,87 & 3,57 \\
\hline 4 Hisse & 1,70 & 1,96 & 2,17 & 1,92 & 1,71 & 1,43 & 2,79 & 2,14 \\
\hline > Hisse & 1,13 & 0,98 & 1,81 & 2,89 & 2,40 & 3,58 & 5,59 & 4,04 \\
\hline $\begin{array}{l}\text { Parsel say1s1 } \\
\text { (adet) }\end{array}$ & $\mathbf{5 2 9}$ & $\mathbf{3 0 6}$ & $\mathbf{5 5 1}$ & $\mathbf{3 1 1}$ & $\mathbf{5 8 4}$ & $\mathbf{2 7 9}$ & $\mathbf{1 1 0 8}$ & $\mathbf{4 2 0}$ \\
\hline
\end{tabular}


Çizelge 11. Toplulaştırmadan önceki ve sonraki ortalama parsel büyüklükleri

\begin{tabular}{|c|c|c|c|c|c|c|c|c|}
\hline \multirow[t]{2}{*}{$\begin{array}{l}\text { Yerleşim } \\
\text { birimi }\end{array}$} & \multirow{2}{*}{$\begin{array}{l}\text { İşletme } \\
\text { adedi } \\
\text { (kişi) }\end{array}$} & \multirow{2}{*}{$\begin{array}{l}\text { Ortalama } \\
\text { işletme } \\
\text { büyüklügüü } \\
\text { (da) }\end{array}$} & \multicolumn{3}{|c|}{$\begin{array}{l}\text { Beher işletmenin ortalama } \\
\text { parsel adedi }\end{array}$} & \multicolumn{3}{|c|}{ Ortalama parsel alanı (da) } \\
\hline & & & АТPÖ & ATPS & $\begin{array}{c}\text { Azalma } \\
(\%)\end{array}$ & ATPÖ & ATPS & $\begin{array}{l}\text { Artma } \\
(\%)\end{array}$ \\
\hline Yenipazar & 1224 & 9,30 & 1,36 & 0,96 & 142,15 & 6,83 & 9,71 & 1,42 \\
\hline Alhan & 573 & 5,93 & 1,48 & 0,84 & 176,62 & 4,02 & 7,10 & 1,77 \\
\hline Çulhan & 638 & 5,96 & 1,49 & 0,84 & 176,21 & 4,01 & 7,06 & 1,76 \\
\hline Dereköy & 482 & 7,59 & 1,55 & 0,88 & 176,78 & 4,91 & 8,67 & 1,77 \\
\hline Hamzabali & 819 & 9,16 & 1,82 & 0,98 & 184,95 & 5,04 & 9,33 & 1,85 \\
\hline Alanl1 & 362 & 7,93 & 1,46 & 0,85 & 172,88 & 5,43 & 9,38 & 1,73 \\
\hline Gödrenli & 499 & 6,80 & 1,16 & 0,69 & 172,22 & 5,75 & 9,76 & 1,72 \\
\hline Kirklar & 326 & 8,96 & 1,79 & 0,86 & 209,32 & 5,00 & 10,47 & 2,09 \\
\hline Dalama & 531 & 10,04 & 2,09 & 0,79 & 263,81 & 4,81 & 12,69 & 2,64 \\
\hline Toplam & 5454 & 8,05 & 1,55 & 0,87 & 178,93 & 5,18 & 9,28 & 1,79 \\
\hline
\end{tabular}

\section{SONUÇ}

Bu çalışmada; Aydın koşullarında yürütülen toplulaștırma sahalarındaki arazi varlığı ve parsel hisselilik durumları karşılaştırılmıştır. Bu kapsamda, Aydın Bölgesi'nin en önemli ovasından bir tanesi olan ve proje alanı 4389 ha olan Yenipazar ovası, Akçay Sol Sahil sahil sulama kapsamında bulunan 9 yerleşim birimi incelenmiştir. Bu çalışmadan elde edilen sonuçlar aşağıda özetlenerek verilmiştir.

Arazi toplulaştırması öncesinde 0-4,99 dekar arasında alana sahip parsel sayısı 5 513; 5-9,99 dekar arasında alana sahip parsel sayıs ise $2038^{\prime}$ dir. $\mathrm{Bu}$ parsellerin kapladıkları toplam alanlar ise sirasıyla 12 241 dekar ve 14033 dekardir.

Toplulaştırma sonrası parsel büyüklükleri incelemesinde toplam parsel say1s1 4 731, parsellerin toplam alanı ise 41730 dekardır. 0-4,99 dekar arasında alana sahip parsel sayısı 1955 , toplam parsel sayısına oranı ise \% 41 alan olarak 5905 dekardır. Diğer taraftan parsellerin \% 32'si 5-9,99 dekar büyüklüğünde olup toplam kapadıkları alan ise 11126 dekardır.

Toplulaştırma öncesinde ve sonrasında tek kișiye ait parsel oranları en yüksek değer almıș olup toplulaştırmadan önce tek hisseli parsel sayısı 7088 iken, toplulaştırma sonunda tek hisseli parsel sayısı 4 080'e düşmüştür. Tüm proje sahasına bakıldığında bu değerler \% 76,19-\% 9311 arasında değişmiştir. Diğer taraftan iki kişiye ait parsellerin hisselilik oranları ise \% 3,81- \% 14,04 arasında bulunmuştur. Proje sahasında 3 ve daha fazla kișiye ait hisselilik oranları ise $\% 0,44-\% 6,86$ arasındadır.

Proje sahası ortalama parsel alanlarına bakıldığında; toplulaştırma öncesi 5,18 da olan ortalama parsel alanı toplulaştırma sonrası 9,28 da'a yükselmiș ve artma oranı \% 1,79 olarak belirlenmiștir.

Sulama projelerinden optimum düzeyde yararın sağlanması için, söz konusu projelerin arazi toplulaştırma çalışmalarıyla birlikte ele alınma gerekliliği saptanmıştır. Bu sebeple yeni projelerde bu durumun mutlaka göz önünde tutulması lazım gelmektedir. Bunların yanında geçmiş dönemlerde projelendirilip tamamlanmış olan sulama çalışmalarının bulunduğu sahaların ise tekrardan revize edilerek arazi toplulaştırma uygulanması ülkemiz toprak ve su kaynaklarının sağlıklı bir șekilde yönetilebilmesi için hayati önem arz etmektedir.

\section{KAYNAKLAR}

Abacı M (2009) Sinop Boyabat Durağan Katılımcı Arazi Toplulaştırma Projesi Yayınlanmamış Değerlendirme Özeti. Tarım Reformu Bölge Müdürlüğü, Samsun.

Akçay SM (2007) Așağı Büyük Menderes Havzası Sulama Şebekelerinin Devir Sonras1 Performanslarının Belirlenmesi. Doktora Tezi, Ege Üniversitesi Fen Bilimleri Enstitüsü, İzmir.

Anonim (2012) Tarım Reformu Genel Müdürlüğü Kayıtları, Ankara.

Anonim (2013b) Aydın Tarım Master Planı. Türkiye Cumhuriyeti Gıda Tarım ve Hayvancılık Bakanlığ 1 , Aydın Gıda Tarım ve Hayvancılık İl Müdürlüğü. Aydın. Anonim (2014) Aydın DMİ Kayıtları, Aydın.

Aslan STA, Gündoğdu KS, Arıcı İ (2007) Some metric indices for the assessment of land consolidation projects. Pakistan Journal of Biological Sciences 10(9): 1390-1397.

Arıcı İ, Akkaya Aslan ST (2010) Arazi Toplulastırma Plan ve Projelemesi. Uludağ Üniversitesi Ziraat Fakültesi Ders Notları No: 105, Bursa.

Ballı B (2005) Türkiye'de Toplulaştırmaya Yönelik Politikalar ve Avrupa Birliği'nde Yeni Toplulaștırma ve Kırsal Kalkınma Yaklaşımları. In: Türkiye'de Arazi Toplulaştırması Sempozyumu Bildirileri, 15-16 Eylül 2005, Konya, 100-141.

Çay T, İnceyol Y (2000) Arazi Toplulaştırması Çalıșalarında Jeodezi ve Fotoğrametri Mühendisliğinin Yeri. Harita Bülteni Sayı: 43.

Çay T, İșcan F (2002) Konya Ovaları Projelerinde Yapılan Arazi Toplulaştırması

Calıșmalarının Değerlendirilmesi. Selçuk Üniversitesi Mühendislik ve Mimarlık Fakültesi Dergisi 17: 2.

Çay T, İşcan F (2005) Karkın Kasabası ve Satır Köyünde Yapılan Arazi Toplulaştırma Çalışmalarının 
Değerlendirilmesi. Türkiye'de Arazi Toplulaştırması Sempozyumu Bildirileri, 15-16 Eylül, Konya, 12-26.

Çelebi M (2010) Toplulaştırmanın Karaman ilinde sulama ve diğer tarımsal faaliyetlerin verimliliği üzerinde etkileri. Tarım Bilimleri araștırma Dergisi 3(2): 1-6.

Çevik B (1974) Konya İli Çumra-Karkın Köyünün Kültürteknik Sorunları ve Bu Sorunların Cözümünde Arazi Toplulaştırmasının Yeri ve Önemi Üzerine Bir Araștırma. Ankara Üniversitesi Basımevi, Ankara.

Hung PV, MacAulay TG, Marsh SP (2007) The economics of land fragmentation in the north of Vietnam. The Australian Journal of Agricultural and Resource Economics, 51: 195-211.

Itır O (2013) Kayseri-Melikgazi-Sarımsaklı Köyü Arazi Toplulaştırma Projesi ve Toplulaştırma Sonrasında Yol-Parsel Durumlarının Analizi. Yüksek Lisans Tezi, Ankara Üniversiteisi, Fen Bilimleri Enstitüsü, Ankara.

Kır M (2012) Sinop Boyabat Cemalettin Köyü Arazi Toplulaştırmasının Tarımsal Altyapı Hizmetleri Yönünden Değerlendirilmesi. Yüksek Lisans Tezi, Gazi Osman Paşa Üniversitesi, Fen Bilimleri Enstitüsü, Tokat.

Kirmikil M, Arıcı İ, Akkaya Aslan ŞT (2010) Sulama Proje Alanlarında Kırsal Alanların Geliștirilmesi için Arazi Toplulaştırmasının Rolü. In: I.Ulusal Sulama ve Tarımsal Yapılar Sempozyumu Bildirileri, 27-29 Mayıs 2010 Kahramanmaraş, 624-638.

Köse T (2009) Arazi Toplulastırmasının Sulama Sistemlerine Etkisi (Manisa Salihli Sağ Sahil Sulama Alanı Örneği. Yüksek Lisans Tezi, Ankara Üniversitesi, Fen Bilimleri Enstitüsü Tarımsal Yapılar ve Sulama Ana Bilim Dalı, Ankara.

Özer A (2010) Çanakkale İli Biga İlçesi Yeniçiftlik Köyü Arazi Toplulaştırması Sonrası Durumun İzlenmesi ve Değerlendirilmesi. Yüksek Lisans Tezi, Çanakkale Onsekizmart Üniversitesi Fen Bilimleri Enstitüsü, Çanakkale.

Parlak Z (2010) Yaşanabilir Bir Kırsal Olușturmak "Arazi Toplulaştırması", http://www.tarimreformu.gov.tr/ library/belge/kitap/Kirsal alan arazi toplulastirma z iya parlak\%20.pdf Erișim tarihi: 01.̄11.2010.

Takka S (1993) Arazi Toplulaştırması. Kültürteknik Derneği Yayınları, No: 1,Ankara.

Yağanoğlu AV, Okuroğlu M, Hanay A (2000) Arazi Toplulaştırmasi. Atatürk Üniversitesi Ziraat Fakültesi Ders Yayınları No:159, Erzurum.

\section{Sorumlu Yazar}

NecdetDAĞDELEN
ndagdelen@adu.edu.tr

AdÜZiraat Fakültesi

Biyosistem Mühendisliği Bölümü

AYDIN

Gelis Tarihi $\quad: 18.01 .2016$

Kabul Tarihi $\quad: 25.01 .2016$ 
